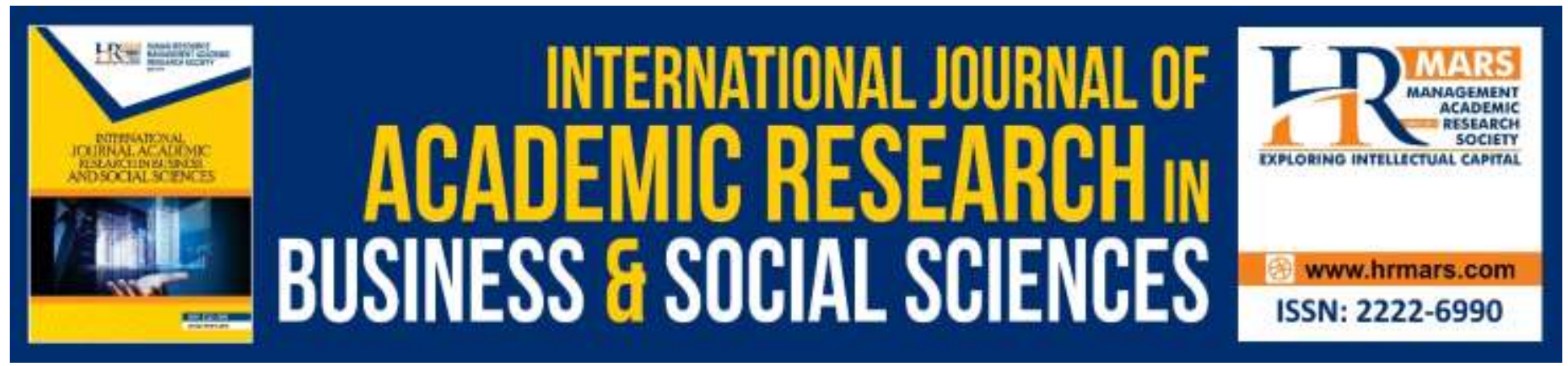

\title{
The Concept of Ulul Albab Principal Leadership
}

\section{Yusrina Jaffar, Ahmad Zabidi Abdul Razak, Rahimah Embong, Mohd Hasrul} Shuhari

To Link this Article: http://dx.doi.org/10.6007/IJARBSS/v9-i11/6593 DOI: 10.6007/IJARBSS/v9-i11/6593

Received: 17 October 2019, Revised: 02 November 2019, Accepted: 13 November 2019

Published Online: 21 November 2019

\section{In-Text Citation: (Ling et al, 2019)}

To Cite this Article: Jaffar, Y., Razak, A. Z. A., Embong, R., Shuhari, M. H. (2019). The Concept of Ulul Albab Principal Leadership. International Journal of Academic Research in Business and Social Sciences, 9(11), 726731.

\section{Copyright: (C) 2019 The Author(s)}

Published by Human Resource Management Academic Research Society (www.hrmars.com)

This article is published under the Creative Commons Attribution (CC BY 4.0) license. Anyone may reproduce, distribute, translate and create derivative works of this article (for both commercial and non-commercial purposes), subject to full attribution to the original publication and authors. The full terms of this license may be seen

at: http://creativecommons.org/licences/by/4.0/legalcode

\section{Vol. 9, No. 11, 2019, Pg. 726 - 731}

Full Terms \& Conditions of access and use can be found at http://hrmars.com/index.php/pages/detail/publication-ethics 


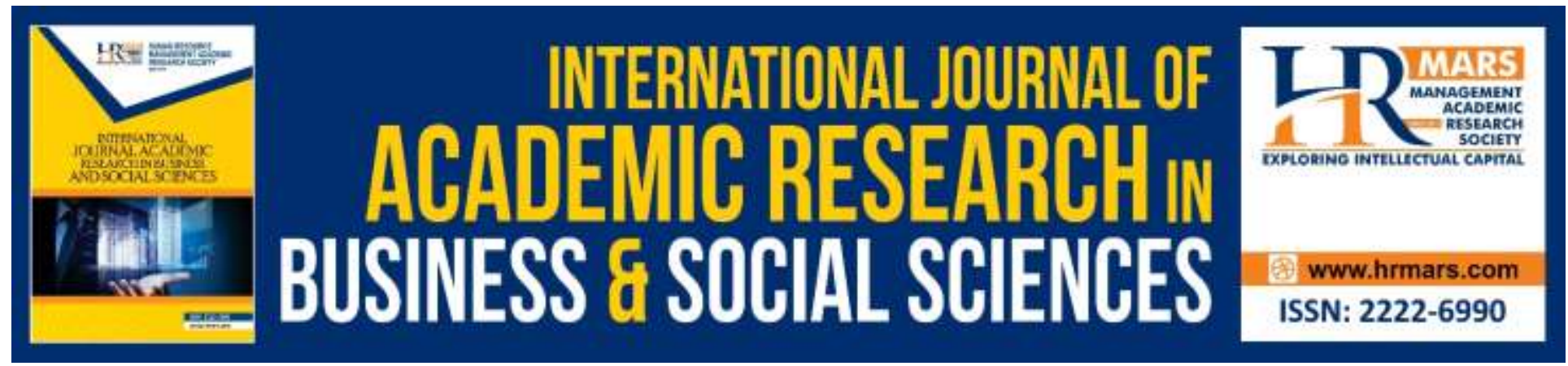

\title{
The Concept of Ulul Albab Principal Leadership
}

\author{
Yusrina Jaffar, Ahmad Zabidi Abdul Razak \\ Faculty of Education, University of Malaya, Malaysia \\ Rahimah Embong, Mohd Hasrul Shuhari \\ Faculty of Islamic Contemporary Studies, Universiti Sultan Zainal Abidin
}

\begin{abstract}
Leadership issue is one of the vital elements in achieving success of a school organization. This issue has been debated among educational reseachers and scholars from time to time. However Islamic leadership theory is still less emphasized in schools compared to Western leadership theory. Thus, this article aims to elucidate the concept of Ulul Albab leadership and identify its distinguished characteristics. Notwithstanding this Ulul Albab concept has been implemented in several schools, its achievement also requires dynamic leadership. It is found that the Ulul Albab leadership has three main dimensions namely Quranic, Encyclopedic and ljtihadikc and these are in line with the Quranic verses (16 verses) related to the Ulul Albab theme. The findings give some implications on the leadership of future leaders and generations.
\end{abstract}

Keywords: Ulul Albab, Leadership, Principal, School, Islamic Education

\section{Introduction}

The aspect of leadership is one of the key elements in providing quality education. The importance of this element of leadership has been debated among scholars for the past four decades and, this matter is continuously discussed at this present days (Kozlowski \& Doherty, 1989). In order to ensure every school achieving excellence in all aspects especially academic, co-curriculum and personality, a principal needs to play active role in promoting excellent school culture (Bush and Bell, 2008). Therefore, leadership styles have been studied continuously and widely from various contexts and dimensions. However, most prior studies were focusing on the aspects of knowledge and skills with but less emphasize the value of life (Bush \& Glover 2003).

The key elements of the Ulul Albab leadership emphasize knowledge, skills and values. Through the infusion of these three elements in school organization, principals will able to understand and practice the Ulul Albab leadership as it has been interpreted as an individual who thinks and acts based on his or her pure soul. In reality, weakness will come out when the 
INTERNATIONAL JOURNAL OF ACADEMIC RESEARCH IN BUSINESS AND SOCIAL SCIENCES

Vol. 9, No. 11, November, 2019, E-ISSN: 2222-6990 @ 2019 HRMARS

principals are still unable to grasp, appreciate and practice the true concept and traits of Ulul Albab leadership (Taib, 2016; Khatatneh \& Teh, 2018; Samat, Ghaffar, Manickam, \& Yunus, 2019).

\section{Leadership Issue}

Empirical studies have shown that principal leadership is one of the key factors in determining the success of an organization (Awang, 2014). However, studies in the public secondary schools in Malaysia have found that the leadership aspect is one of necessary matters that should be taken into account. This situation becomes problematic to the education system in this country. Consequently, various theories and models of leadership have been constantly reviewed for the purpose of improving this situation from time to time.

It is found that studies on leadership related to religion are still lacking. Leadership theories discussing values should be developed to solve the problem of insufficient studies in this issue. In fact, schools leaders are still exploring for leadership styles necessary to practice based on the characteristics or types of schools they lead (Shariff, 2009; Ugwu, Udeh, 2018).

Theoretically, many leadership researchers view that principals often practice different styles of leadership depending on the nature or type of their schools. As mentioned by Abdullah (2004), the culture or type of a school can influence the leadership style of a principal. For example, full boarding schools require different style of leadership from the ordinary public schools. This matter indicates the influence of school types on principals' leadership practices.

The repetition of the Ulul Albab term for 16 times in the Holy Quran illustrates the vital need of producing such group of Ulul Albab leaders for the development of a community (Mohd Radzi Taib, 2016). Hence, what are the traits or characteristics of this Ulul Albab group could be derived from these Quranic verses? How can the concept of the Ulul Albab could be applied in this contemporary world and current context? More importantly, how can the Ulul Albab group eventually become global leaders?

The concept of Ulul Albab could be realized in our education system as the improvement could be done through the learning system that being reinforced with values. For example, this concept of Ulul Albab has been manifested into Imtiaz Schools, where the students' achievement in the national examinations was very encouraging and excellent as they are mastering in the preservation of the Holy Quran. Therefore, this article aims to identify the main characteristics of Ulul Albab leadership that emphasize knowledge, skills and values based on the perspective of teachers and students.

\section{The Concept of Ulul Albab Leadership}

The definition of Ulul Albab Leadership is referring to the word 'Ulul al-Bab'. The word "albab" is jama' (plural) derived from the word "lubbun" which means intellectuality originating from the deep of the heart. The term of Ulul Albab has been mentioned 16 times in the Holy Quran without explaining its meaning. Among the Quranic verses mentioning this term of Ulul Albab are Surah al-Baqarah; verses 179, 197 and 269, Surah az-Zumar; verses 9,18 and 21, Surah Ali Imran; verses 7 and190, Surah ar-Raentiu; verse 19, Surah Ibrahim; verse 52, Surah Sod; verses 29 and 43, Surah 
Ghafir; verse 54, Surah Yusof; verse 111, Surah al-Maaidah; verse 100, and Surah at-Talak; verse 10 (Taib, 2016).

Based on the term of Ulul Albab mentioned in the above Qur'anic verses, it could be derived some distinguished traits for Ulul Albab leaders who have thinking, utilizing their mind, sound mind, mindfulness and taking lessons or wisdom, the sound mind (so that they may be patient during misfortunes), taking lessons and reminders as well as remembering the God Almighty at all situations including standing, sitting or lying down, and always thinking of the creation of heaven and earth.

\section{Traits of Ulul Albab Leadership}

The traits of the Ulul Albab leadership can be adapted from the Ulul Albab Curriculum Principles in the MRSM Education System. Subsequently, this notion is applied to a number of selected National Religious Secondary Schools as well as the national education system as a whole in order to meet current changes in Malaysia. The curriculum is divided into three basic areas or dimensions: Quranic, Encyclopedic and ijtihadic (Taib, 2016).

\section{Quranic}

The traits of the Quranic Ulul Albab leadership are having awareness and faith in the truth of the Quran, taking the Quran as reminder and reference of God's magnificence, taking lessons from revealed book, obtaining revealed guidance and reminders, having faith and piety with the God's punishment (Taib, 2016).

\section{Encyclopedic}

Ulul Albab Leadership based on Encyclopedic (knowledge) refers to the concept of intellectual intelligence (IQ-knowledge) and the concept of cleverness (IQ-skills). The fundamental principle of Islamic leadership is the emphasis of knowledge quality, both leaders and subordinates of an organization (Ab. Ghani and Mansor, 2006; Taib, 2016).

\section{ljtihadic}

The appropriate traits of ljtihadic for a leader are; be mind-hearted and pious, consistently equip himself with piety, take wisdom from God's message, obedient and always seek God's mercy, listen critically and choose the best, observe and learn from the natural phenomena, always choose goodness and avoid evil, take lessons from past history, and be perseverance and patient (Taib, 2016). 


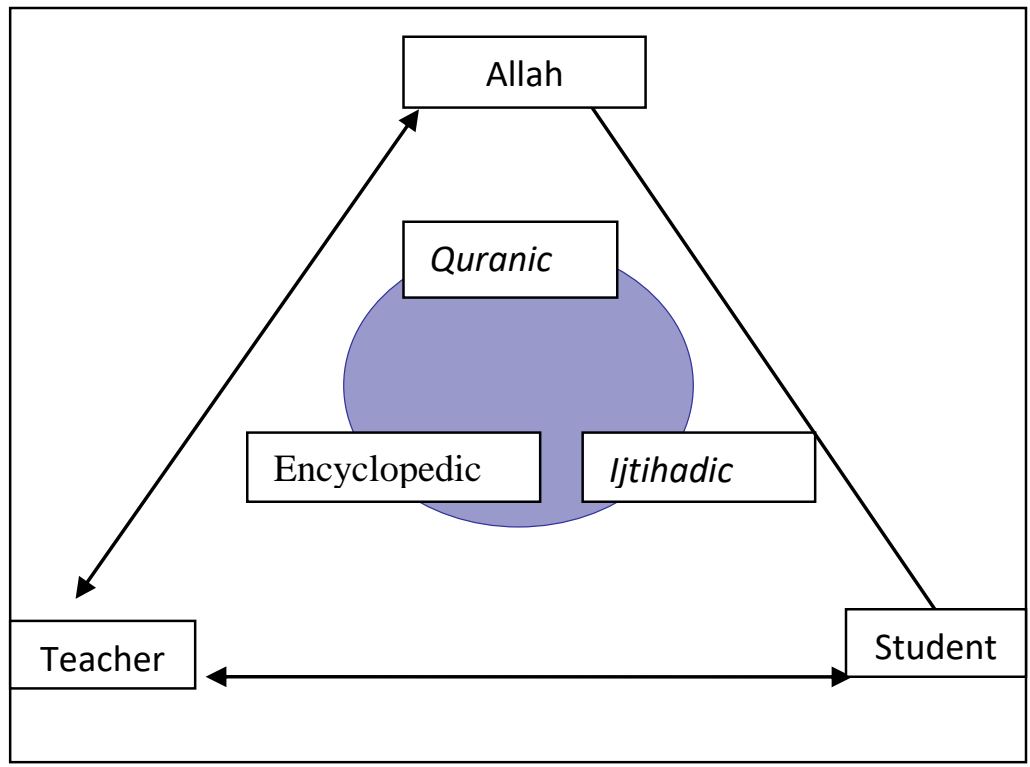

Figure 1: A model of the Ulul Albab Leadership Principal based on Professional Maturity \& Managerial Skill

Figure 1 shows the three-dimensional integration of Quranic, Encyclopedic and ljtihadic that develop the Ulul Albab Leadership theory. Based on these three-dimension, it produces elements of skill in managing an organization that includes skills and knowledge, relationships and motivation. Therefore, a principal can ensure his subordinates to move toward achieving their desired goal.

\section{Conclusions}

The practice in every dimension of Ulul Albab leadership has implications on the pattern and formation of Islamic leadership culture based on the concept of devotion, obedience and piety to Allah SWT. The three dimensions of the Ulul Albab, namely Quranic, Encyclopedic and Ijtihadic, have their own influences in ensuring all members of an organization meet the goals set by the leaders. As such, implementing the best practices of Ulul Albab leadership is expected to enhance the performance of educational institutions throughout the countryin geneeral. Hence, the Ulul Albab leaders need to aware of the traits expected by the largest and most important of school population which consists of teachers and students.

\section{Acknowledgments}

We express our deepest gratitude to Center for Research Excellence \& Incubation Management (CREIM) and Faculty of Islamic Contemporary Studies, Universiti Sultan Zainal Abidin for supporting our intellectual endeavor. 
INTERNATIONAL JOURNAL OF ACADEMIC RESEARCH IN BUSINESS AND SOCIAL SCIENCES

Vol. 9, No. 11, November, 2019, E-ISSN: 2222-6990 @ 2019 HRMARS

\section{Corresponding Author}

Mohd Hasrul Shuhari, Ph.D, is Senior Lecturer at Department of Usuluddin, Faculty of Islamic Contemporary Studies, Universiti Sultan Zainal Abidin (UniSZA), Kampus Gong Badak, 21300 Kuala Nerus. Terengganu, Malaysia.

Email: hasrulshuhari@unisza.edu.my

\section{References}

Ab.Ghani A. M. \& Mansor, F. (2006). Dimensi pengurusan Islam. Kuala Lumpur: University of Malaya Press.

Abdullah, A. G. (2009). Kepimpinan Penambahbaikan Sekolah. Percetakan BS Print (M) Sdn.Bhd. Abdullah, A. S. (2004). Kepimpinan unggul tonggak pengurusan pendidikan cemerlang. Prosiding Seminar Pengurusan dan Kepimpinan Pendidikan ke 12. Institut Aminuddin Baki, Genting Highland.

Awang, M. R. (2014), Pengaruh Amalan Kepimpinan Penolong Kanan Pentadbiran dan Iklim Sekolah Sihat ke Atas Komitmen Guru di Sekolah Menengah Kebangsaan Kluster Kecemerlangan, Unpublished PhD thesis, Universiti Utara Malaysia.

Bush, T., \& Bell, L. (2008). The principles and practices of educational management. London: Sage Publications.

Bush, T., Glover, D. (2003) School Leadership: Concepts and Evidence. A Review of Literature Carried out for National College for School Leadership. National College for School Leadership, Nottingham.

Khatatneh, N. A. K., \& Teh, K. S. M. (2018). Attitudes of Primary School Teachers towards the Use of Computerized Educational Games in the Teaching of English Language. International Journal of Academic Research in Progressive Education and Development, 7(4), 280-294.

Kozlowski \& Doherty, M. L. (1989). Integration of climate and leadership: Examination of a neglected issue. Journal of Applied Psychology, 74(4), 546.

Samat, M. S. B. A., Ghaffar, M. B. A., Manickam, R., \& Yunus, M. M. (2019). Virco To Enhance Reading Comprehension. Multilingual Academic Journal of Education and Social Sciences, 7(1), 71-83.

Sharif, S. M. (2009). Generasi Ulul Albab Segunung Harapan Seteguh Gagasan. Shah Alam: Karisma Publications Sdn. Bhd.

Taib, M. R. (2016), Rekabentuk Model Kepimpinan Ulul Albab Maktab Rendah Sains MARA, Unpublished PhD thesis of education, Universiti Malaya.

Ugwu, J. I., Udeh, S. N. (2018). Influence of Foreign Direct Investment on Exchange Rate and Domestic Investment in Pre- and Post- IFRS Adoption Periods of Selected Sub-Saharan African Countries (1999- 2015), International Journal of Academic Research in Accounting, Finance and Management Sciences 8 (3): 1-16. 